Review

\title{
Impact of the Flipped Classroom Method in the Mathematical Area: A Systematic Review
}

\author{
Francisco-Domingo Fernández-Martín ${ }^{1}{ }^{\mathbb{D}}$, José-María Romero-Rodríguez ${ }^{2}{ }^{\mathbb{D}}$, \\ Gerardo Gómez-García ${ }^{3, * \mathbb{D}}$ and Magdalena Ramos Navas-Parejo ${ }^{3} \mathbb{D}$ \\ 1 Department of Developmental and Educational Psychology, Campus de Cartuja s.n., 18071 Granada, Spain; \\ fdfernan@ugr.es \\ 2 Association for Research and Promotion of Education in the Digital Society-PROMOEDUCA, \\ University of Granada, 1087 Granada, Spain; romejo@ugr.es \\ 3 Department of Didactics and Scholar Organization, Campus de Cartuja s.n., 18071 Granada, Spain; \\ magdalena@ugr.es \\ * Correspondence: gomezgarcia@ugr.es
}

Received: 31 October 2020; Accepted: 1 December 2020; Published: 4 December 2020

\begin{abstract}
Currently, the use of technology has become one of the most popular educational trends in Higher Education. One of the most popular methods on the Higher Education stage is the Flipped Classroom, characterised by the use of both face-to-face and virtual teaching through videos and online material, promoting more autonomous, flexible and dynamic teaching for students. In this work, we started to compile the main articles that used Flipped Classroom within the mathematical area in Higher Education, with the aim of analysing their main characteristics, as well as the impact caused on students. To do so, the method of systematic review was used, focusing on those empirical experiences published in Web of Sciences and Scopus. The results indicated that, in most cases, the implementation of Flipped Classroom led to an improvement in students' knowledge and attitudes towards mathematical content and discipline. In addition, aspects such as collaborative work, autonomy, self-regulation towards learning or academic performance were benefited through this method.
\end{abstract}

Keywords: Flipped Classroom; flipped learning; mathematics; higher education; university

\section{Introduction}

Nowadays, traditional teaching-learning methods have become obsolete and do not respond to the demands of today's students, who behave passively and are unmotivated and do not encourage critical thinking. Likewise, traditional teaching methods do not adapt to the pace of society, which is advancing at a dizzying rate, experiencing important changes in all areas [1]. The work that teachers had done for decades now also needs to be different in order to provide an adequate response to their students [2]. They need to be kept up to date with methodological innovation, which goes far beyond the master class. These new methods prepare students to successfully face the real world, using their knowledge and enabling them to adapt autonomously to the changing pace of society [3]. Thus, we are looking at a revolution in the way we understand and operate the teaching-learning processes, where different skills are proposed and digital resources are incorporated, which also characterise today's society [4]. Information and Communications Technology (ICT) is essential for this methodological change, as they enable students to work independently and in a personalised way. [5].

These innovative strategies called active methodologies offer students a significant role, making them the principal participants in their own learning [6,7]. The Flipped Classroom method, also known as the hybrid model or blended learning, forms part of one of these types of active 
methodologies [8]. It is a methodological proposal based on the theory of social learning and constructivism, so that students are the active actors in their learning [9].

If traditionally, during class time the teacher actively presented the theoretical contents and left the practical part for the students to work at home individually, from this new approach, the organisation and management of time is reversed [10], differentiating two parts: in the first, the students work on the theoretical contents individually, asynchronously and autonomously, before the classroom session. In this phase, ICT play a fundamental role, since these theoretical contents reach the students through videos, images, computer graphics or iconic materials [11]. The second part, coincides with the time in class, during which the questions are raised and the practical work is done; developing the competences and solving problems connected to the real world, in which the theoretical contents learned are used, in a collaborative and active way, under conditions of self-regulation and structuring of cognitive scaffolds [12-16].

The role of the teacher using this methodology is to guide learning, adapting teaching approaches to needs and preparing the different learning scenarios [17].

This method includes three lines of learning: (1) Individual learning, which is adapted to the different learning rhythms, since the contents of the first phase can be visualised as often as necessary, and it encourages responsible and autonomous work. (2) Collaborative learning, worked on during the second phase, where in groups we pursue objectives that are agreed upon until the final objective is reached. (3) Problem-based learning, which also takes place in the second part of this method, in which what is learned is put into practice in a contextualised way, enriched by the contributions of the group's colleagues, and it is checked whether the learning has been effective [18].

The advantages that the Flipped Classroom methodology brings to teaching are the following [19]: It respects learning rhythms, since theoretical explanations can be used at any time, promoting oblique learning [5]. Self-evaluation is made possible, providing constructive feedback on their progress and the quality of their work. It develops responsibility in one's own learning $[17,20]$. It is a methodology which is in accordance with the motivations and interests of the students [21], who tend to prefer virtual environments, to those which they are increasingly used to. It develops autonomy by also increasing their interest and motivation for learning [22], contributing to favour the "learning to learn" competence, so important to acquire in a society that is in continuous change [23]. This autonomy also favours creativity and critical thinking in the student [18]. It develops collaborative teamwork [24] and exposes students to problematic situations that encourage meaningful learning [25], which improves academic performance $[26,27]$.

For this methodology to be effective and for all these educational advantages to be enjoyed, it is essential that teachers have acquired digital competence, which allows them to create audio-visual material and move around content management platforms, as well as having adequate methodological training [28]. Therefore, one of the drawbacks that make the use of this method difficult is the lack of training of the teaching staff in aspects related to innovative methodologies and ICTs, together with the necessary dedication to carry it out and the lack of habit of the students with the invested learning $[29,30]$.

Numerous interventions, particularly in the area of mathematics, at all educational stages, show the benefits of this method for learning in this area [31-35]. Authors such as [36] argue that this form of learning mathematics allows higher levels of Bloom's taxonomy to be worked on in the classroom, such as analysis, which requires more discussion, making the face-to-face class more profitable. To this concept, [37] adds the impact on increasing performance and motivation in this subject, which is often difficult for students to assimilate [38] and together with [39], who also highlight the improvement in the working environment and the attitude of the students.

On the other hand, [40] implemented this method in the differential calculus classroom of higher education, appreciating, from the results obtained, its advantages of motivation and break with the classical routines, as well as the need to develop the methodological foundations of the Flipped Classroom. In this way, the personalization, meaning, idealization and representation of mathematics 
teaching was not impaired, besides the need to take into account the students' previous knowledge. Ref. [41] reiterates the importance of teacher training, which will lead them to change the traditional methodology, accepting the new active methodological strategies, to which they are not used to.

Ref. [42], after the application of this didactic strategy in the secondary education mathematics classroom, obtained as a result a substantial improvement in the evaluation and attitude of the students, verifying the increase in motivation and skills in the analysis and representation of graphics.

Based on these ideas, the main objective of this work was to locate the main educational experiences that would use the Flipped Classroom method for the promotion of mathematical knowledge within the Higher Education stage. With this purpose in mind, the next research questions were configured:

RQ1. What are the main experiences in which the Flipped Classroom method is being implemented to achieve an acquisition of mathematical knowledge?

RQ2. In which disciplines within mathematics are these experiences framed?

RQ3. What journals have published scientific articles on this field?

RQ4. What has been the impact of the Flipped Classroom method on students?

RQ5. What instruments were used to measure the effectiveness of the Flipped Classroom method?

\section{Materials and Methods}

Based on the ideas set out above, this work is part of the systematic literature review method, conceived as that which analyses information provided to generate an overview of a certain object of study, specifically information provided in databases or scientific reports [43]. This type of research allows the categorization of the results to date on the topic, as well as measuring the data based on different criteria regarding the relevant issues that need to be clarified [44,45].

For this purpose, the methodological process consists of a sequence of steps that go from the defining of the scope to the classification of the data obtained. For this purpose, the work phases proposed in the PRISMA declaration (Preferred Reporting Items for Systematic reviews and Meta-Analyses) were followed [46].

The examination process carried out was divided into two steps:

- Planning: This protocol consisted of the definition of the research questions, inclusion and exclusion criteria and the development of the descriptors and databases from which the scientific papers would be collected.

- Action: We proceeded to find references in the selected bases, to refine the data using different filters to extract the information to ultimately make the representation of the data. As for the formulation of the inclusion and exclusion criteria, these were configured according to the objectives of the study and the indications contained in the PRISMA declaration.

\subsection{Search Strategy}

The search of the scientific papers was carried out in the international databases Web of Science (WoS) and Scopus. These two databases were chosen for their potential and international reputation, as well as for the criteria they use to index their articles [47]. In the case of the Web of Sciences, the search was carried out in the Social Sciences Citation Index (SSCI), Science Citation Index Expanded (SCIE) and Arts and Humanities Citation Index (AHCI). The search equation was used, which is composed of the following descriptors: "Flipped Classroom" or "Flipped Learning", and "Mathematics".

The descriptors were applied in the searching engine of both databases in order to filter them further. In order to do so, a list of inclusion and exclusion criteria was set up to limit the study sample (Table 1).

To avoid any bias in the selection of the studies, after other works of systematic review [48], two researchers conducted the systematic review using the identical descriptors and criteria for inclusion and exclusion. The degree of consensus in the inclusion of the article was $95 \%$. The disagreement was addressed by a third researcher who chose to include $100 \%$ of the extracted scientific literature. 
Table 1. Inclusion and exclusion criteria.

\begin{tabular}{|c|c|}
\hline Inclusion Criteria (IC) & Exclusion Criteria (EX) \\
\hline IC1: Journal articles & $\begin{array}{l}\text { EX1: Book chapters, books, or other types of } \\
\text { non-peer-reviewed publications. }\end{array}$ \\
\hline IC2: Articles available in Open Access & EX2: Articles not available in Open Access \\
\hline IC3: Empirical rese & EX3: Theoretical studies or revisions. \\
\hline IC4: Articles written in English or & EX4: Articles that are not written in English or \\
\hline Spanish language. & Spanish language. \\
\hline IC5: Research that has taken place in the Higher & EX5: Practices that have not been implemented in other \\
\hline \multirow{3}{*}{$\begin{array}{l}\text { IC6: Educational experiences in which I used the } \\
\text { Flipped Classroom method within the } \\
\text { mathematical field }\end{array}$} & \\
\hline & $\begin{array}{l}\text { EX6: Educational experiences in which I used the Flipped } \\
\text { Classroom method in another discipline of knowledge. }\end{array}$ \\
\hline & EX7: Duplicate Articles \\
\hline
\end{tabular}

\subsection{Procedure}

First, using the Prism Declaration [46,49] as a reference, the procedure was divided into four specific phases. The first, called "Identification", consisted of applying the database search equation, filtering the search for scientific articles (IC1, EX1) in English or Spanish (IC3, EX3), obtaining a total of 10 documents (WoS; Scopus). After that, in the review phase, most of the inclusion criteria (IC2, IC4, IC5) and exclusion criteria (EX2, EX4, EX5) were applied. Finally, duplicate articles were eliminated (EX7) in order to finally obtain a sample of articles to be analysed $(n=10)$.

In order to shorten this procedure, a flow chart is presented that shows the process described from the initial location of documents to the final scrutiny of the sample of articles that make up the systematic review study (Figure 1).

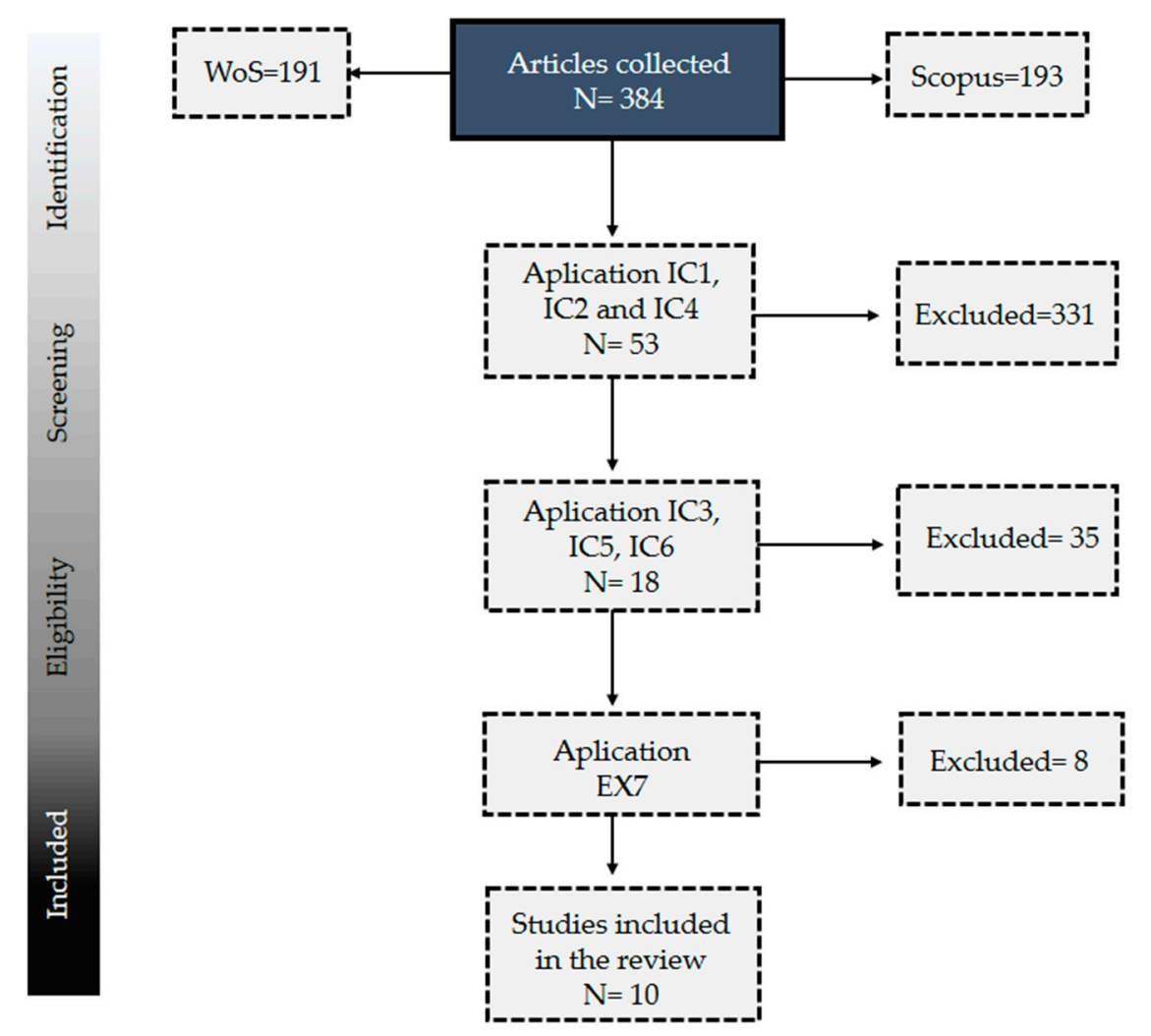

Figure 1. Flowchart of the phases that make up the systematic review. 


\section{Results}

First, the studies were grouped according to the year in which they were published (Figure 2). In this case, it can be seen that the year 2019 was the one with the most contributions, followed by 2016, 2018 and 2017, respectively.

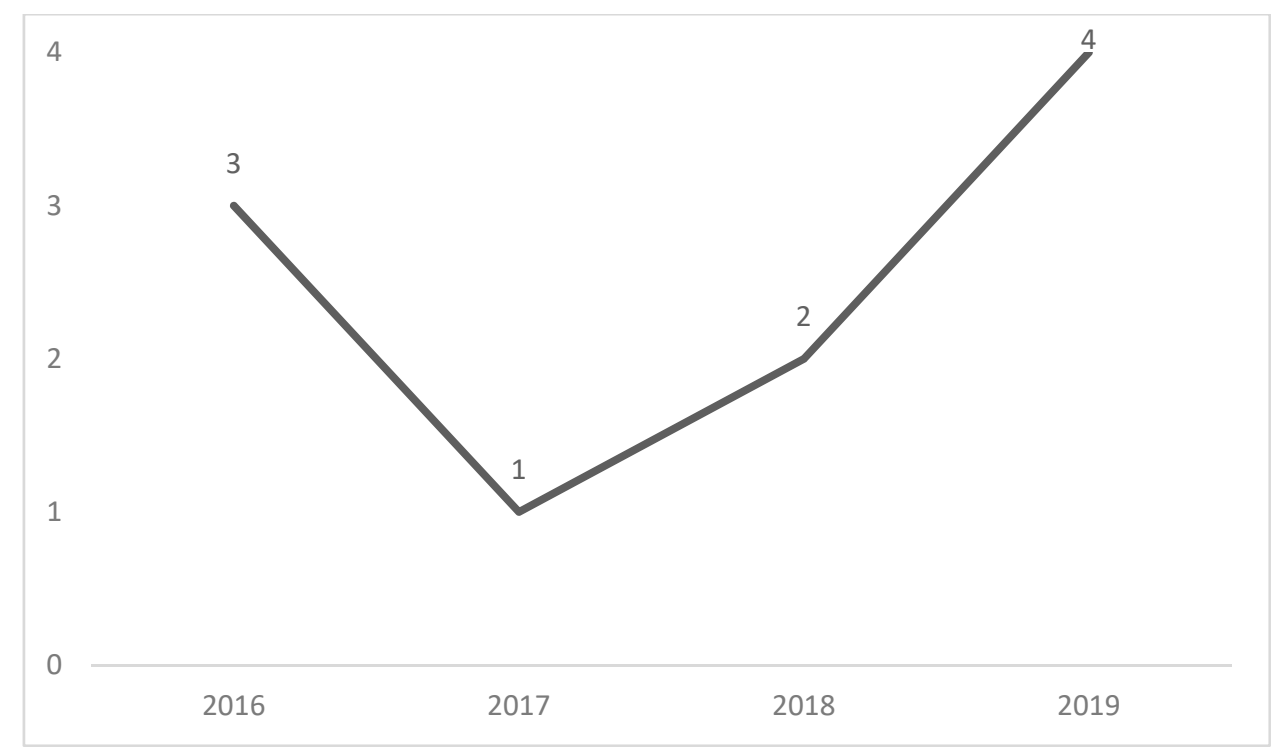

Figure 2. Number of articles per year.

On the other hand, looking at the journals in which these scientific papers have been published (Table 2), it can be seen that the articles have been published in different platforms. In particular, Educational Technology, E Society stands out, with a total of two works on this topic. According to the origin of the journals, they correspond to different countries, among which the United Kingdom stands out, with a total of four publications.

Table 2. Journals to which the works belong and country.

\begin{tabular}{ccc}
\hline Reference & Journal & Country \\
\hline$[50]$ & Tecné Episteme y Didaxis: TED & Colombia \\
{$[51]$} & Higher Education Pedagogies & United Kingdom \\
{$[52]$} & International Journal of Interactive Mobile Technologies & Germany \\
{$[53]$} & International Journal of Higher Education & Canada \\
{$[54]$} & CBE-Life Sciences Education & United States \\
{$[55]$} & Journal of Technology and Science Education & Spain \\
{$[56]$} & International Journal of Mathematical Education in Science and Technology & United Kingdom \\
{$[57]$} & PRIMUS: Problems, Resources, and Issues in Mathematics Undergraduate Studies & United Kingdom \\
{$[58]$} & Research and Practice in Technology Enhanced Learning & Singapore \\
{$[59]$} & Teaching Mathematics and Its Applications & United Kingdom \\
\hline
\end{tabular}

According to the mathematical contents that have been addressed during the Flipped experiences, it mainly corresponds to the treatment of the derivative and the limit of functions (Table 3). However, there are also works coming from the computer, algebraic and even didactic field. 
Table 3. Mathematical content covered in each educational experience.

\begin{tabular}{cc}
\hline Reference & Mathematical Content \\
\hline$[50]$ & The derivative as a ratio of change, incremental coefficient. Optimization of functions \\
{$[51]$} & Limits and derivatives \\
{$[52]$} & Mathematical modelling \\
{$[53]$} & Gaussian elimination method \\
{$[54]$} & Critical thinking in the STEM area \\
{$[55]$} & Didactic programming in the area of Mathematics \\
{$[56]$} & Computer programming \\
{$[57]$} & Language in Mathematics \\
{$[58]$} & Limit of functions, differentiation, applications of derivatives, and theory of integration \\
{$[59]$} & with applications \\
\hline
\end{tabular}

Finally, the objectives of each investigation were analysed in detail, as well as the methodology used and the impact on students after the application of the methodology (Table 4). In general terms, all the studies claim that the application of Flipped Classroom has improved students' attitudes towards the content taught, and in some cases towards the mathematical discipline $[51,56]$. In addition, parallel aspects of learning benefit, such as self-regulation [57], collaborative learning and the social climate of the classroom [52] and improved academic performance [55]. On the other hand, the methodological plurality found in the methodology employed by the authors is also noteworthy, with qualitative and quantitative works, as well as experimental, quasi-experimental designs, of a comparative nature between academic years.

Table 4. Mathematical content covered in each educational experience.

\begin{tabular}{|c|c|c|c|c|}
\hline Reference & Objective & Method & Instrument & Impact of FC Application \\
\hline$[50]$ & $\begin{array}{l}\text { To analyse the } \\
\text { effectiveness of the } \\
\text { Flipped Classroom } \\
\text { method in the } \\
\text { assimilation of the } \\
\text { derivative in the } \\
\text { resolution of application } \\
\text { exercises }\end{array}$ & Qualitative & Written test & $\begin{array}{l}\text { Increase in students' motivation, } \\
\text { as well as their capacity to argue } \\
\text { mathematical problems. However, } \\
\text { the freedom of students to use } \\
\text { information sources in their "out } \\
\text { of class" period, or the traditional } \\
\text { character of algorithmic work } \\
\text { under this methodology, were not } \\
\text { considered as negative aspects. }\end{array}$ \\
\hline$[51]$ & $\begin{array}{l}\text { What is the influence of } \\
\text { Flipped Classroom on } \\
\text { the attitude towards } \\
\text { mathematics in students } \\
\text { depending on their } \\
\text { socio-economic level? }\end{array}$ & $\begin{array}{l}\text { Quantitative } \\
\text { pre-post test. } \\
\text { Existence of } \\
\text { control and } \\
\text { experimental } \\
\text { group }\end{array}$ & $\begin{array}{l}\text { The Attitudes } \\
\text { Towards } \\
\text { Mathematics } \\
\text { Inventory } \\
\text { (ATMI) }\end{array}$ & $\begin{array}{l}\text { The groups that experienced } \\
\text { Flipped Classroom increased their } \\
\text { participation and commitment in } \\
\text { class. Students who came from } \\
\text { more vulnerable environments } \\
\text { rated the pedagogical change } \\
\text { more positively. }\end{array}$ \\
\hline [52] & $\begin{array}{l}\text { Promote through } \\
\text { Flipped Classroom a } \\
\text { better understanding of } \\
\text { mathematical modelling } \\
\text { concepts. }\end{array}$ & Mixed & $\begin{array}{l}\text { Self-observation, } \\
\text { ad-hoc } \\
\text { questionnaire } \\
\text { and student } \\
\text { diary }\end{array}$ & $\begin{array}{l}\text { The experiment led to an } \\
\text { improvement in the social climate } \\
\text { of the students, improving } \\
\text { collaborative work between them } \\
\text { in the classroom. In turn, it } \\
\text { allowed students to better control } \\
\text { their learning time, as some of } \\
\text { them repeated the videos if they } \\
\text { did not understand the content. } \\
\text { The students' perception of the } \\
\text { usefulness of the class was } \\
\text { increased. }\end{array}$ \\
\hline
\end{tabular}


Table 4. Cont.

\begin{tabular}{|c|c|c|c|c|}
\hline Reference & Objective & Method & Instrument & Impact of FC Application \\
\hline [53] & $\begin{array}{l}\text { Acquire the Gaussian } \\
\text { elimination method } \\
\text { through the Flipped } \\
\text { Classroom model }\end{array}$ & Qualitative & $\begin{array}{l}\text { Participant } \\
\text { observation }\end{array}$ & $\begin{array}{l}\text { Through the previous phase at } \\
\text { home, the students acquired the } \\
\text { basic notions about the method. } \\
\text { Later, in the classroom, through } \\
\text { Matlab they were able to deepen } \\
\text { their learning. Therefore, the } \\
\text { learning was more effective. }\end{array}$ \\
\hline [54] & $\begin{array}{l}\text { To evaluate the impact of } \\
\text { the Flipped Classroom } \\
\text { method on the } \\
\text { mathematical thinking of } \\
\text { life science students, } \\
\text { with emphasis on critical } \\
\text { thinking }\end{array}$ & Quantitative & $\begin{array}{l}\text { California } \\
\text { Critical } \\
\text { Thinking Skills } \\
\text { Test, \& Student } \\
\text { Assessment of } \\
\text { their Learning } \\
\text { Gains (SALG) }\end{array}$ & $\begin{array}{l}\text { Students' critical thinking } \\
\text { developed considerably. } \\
\text { Especially, when evaluating } \\
\text { mathematical information, } \\
\text { expressing their arguments and in } \\
\text { confidence when expressing their } \\
\text { reasoning. }\end{array}$ \\
\hline
\end{tabular}

The purpose of this

study has been to

analyse student

satisfaction after the implementation of the

[55] flipped learning model in online learning, as well as to study whether there is an improvement in the performance of these students.
Student satisfaction improved after the course of the flipped course, and an improvement in student academic performance was noted. Students say they would repeat the experience
Quasi-
Ad-hoc survey

The fact that time in class was

Student

Experience of Course (SEC) used in an active way, which was not contemplated in the traditional methodology, was valued very positively. experimenting with Flipped Classroom? between the

application in two different academic years

\begin{tabular}{|c|c|c|c|c|}
\hline [57] & $\begin{array}{l}\text { Check the results of the } \\
\text { Communications in } \\
\text { Mathematics program } \\
\text { through following a } \\
\text { Flipped Classroom } \\
\text { methodology }\end{array}$ & $\begin{array}{l}\text { Mixed with } \\
\text { experimental } \\
\text { character } \\
\text { applying } \\
\text { pre-test and } \\
\text { post-test. }\end{array}$ & $\begin{array}{l}\text { Motivated } \\
\text { Strategies for } \\
\text { Learning } \\
\text { Questionnaire } \\
\text { (MSLQ), and } \\
\text { open questions }\end{array}$ & $\begin{array}{l}\text { The students valued the } \\
\text { experience positively. There was a } \\
\text { slight improvement in student } \\
\text { self-regulation towards learning } \\
\text { during the course. There was also } \\
\text { strong resistance to adapt to the } \\
\text { method. }\end{array}$ \\
\hline [58] & $\begin{array}{l}\text { Checking students' } \\
\text { attitudes after the } \\
\text { application of Flipped } \\
\text { Classroom in learning } \\
\text { limits, derivatives and } \\
\text { application theory with } \\
\text { applications }\end{array}$ & Mixed & Ad hoc survey & $\begin{array}{c}\text { The reaction of the students was } \\
\text { positive, who, in generic terms, } \\
\text { presented positive attitudes } \\
\text { towards the methodology. } \\
\text { However, there were students } \\
\text { who did not follow the video } \\
\text { viewing. }\end{array}$ \\
\hline [59] & $\begin{array}{l}\text { To evaluate the } \\
\text { effectiveness of Flipped } \\
\text { Classroom in the } \\
\text { development of } \\
\text { algebraic calculus of } \\
\text { different groups of } \\
\text { science students }\end{array}$ & $\begin{array}{c}\text { Quantitative. } \\
\text { Quasi- } \\
\text { experimental }\end{array}$ & $\begin{array}{c}\text { The } \\
\text { Mathematics } \\
\text { Attitudes and } \\
\text { Perceptions } \\
\text { Survey (MAPS), } \\
\text { and The } \\
\text { Calculus } \\
\text { Concept } \\
\text { Inventory }\end{array}$ & $\begin{array}{l}\text { Those students with lesser skills } \\
\text { in calculus showed significant } \\
\text { improvements after the } \\
\text { experimentation of the method. } \\
\text { However, those students with a } \\
\text { higher level did not experience } \\
\text { any benefit. }\end{array}$ \\
\hline
\end{tabular}




\section{Discussion and Conclusions}

The implementation of Flipped Classroom is considered as one of the latest and most relevant methodological innovations in recent years. Specifically, in the field of mathematics, the arrival of this teaching methodology has led various Higher Education teachers to incorporate it into their daily work in the classroom [34,35]. The aim of this study was to analyse the main experiences using this methodology when teaching mathematics, and to see what effect it had on students.

Thus, the main findings of the work indicated that in the majority of the investigations analysed, the implementation of Flipped Classroom meant a notable improvement in students' knowledge of the specific content covered, as was the case of algebraic calculation, the derivation and limits of functions, mathematical modelling and mathematical critical thinking, among others. Therefore, this finding adds to the ideas indicated by previous studies that determine the effectiveness of Flipped Classroom in this sense $[34,40]$.

Likewise, the experimentation of the method promoted an improvement in the motivation rates of the students, as well as a more positive evaluation towards the contents and, in general, towards mathematics [51]. Therefore, we continue on a path, as corroborated by the scientific literature, of improvement in the motivation rates after the implementation of active methodologies that integrate technology in their teaching procedures $[37,42]$.

Similarly, the improvement of aspects such as collaborative learning within the classroom activity, as well as autonomous learning, should also be highlighted. With regard to the former, dividing the teaching process into two phases encourages that time in the classroom to be dedicated to active and collaborative learning, in which students take on a greater role, giving rise to a better social climate and better group synchrony [24]. On the other hand, placing part of the activity of the methodology outside the classroom promotes the development of self-regulation and autonomy skills towards learning. However, this assertion cannot be fully corroborated, since in turn, the results of this review determined that although the majority of students fulfilled this purpose, a minority group was found not to follow the Flipped videos and that they presented greater difficulty in incorporating themselves into the new class dynamic $[57,58]$. In view of this situation, it is necessary to continue working on didactic strategies and the implementation of resources that allow the entire student body to be correctly incorporated into this method.

In short, the implementation of active methodologies such as Flipped Classroom is becoming an emerging practice that is gaining prominence within the mathematical landscape. The arrival of technology in the classroom has changed the concept of teaching, in favour of online education, student autonomy and the practical nature of classroom attendance.

Among the limitations of this work is that it was not possible to analyse those studies that were not in Open Access, which limited the sample of studies to a small number. In this way, there is a part of the scientific literature that cannot be analysed and interpreted. On the other hand, the future lines of research are to continue promoting the use of the Flipped Classroom method within the mathematical branch as one of the main lines of innovation at a didactic level. The proposal of good practices in this sense, will provide teachers of all educational stages in the area of mathematics with ideas to be able to undertake in their classroom and promote an improvement through technology.

In conclusion, the dizzying technological progress experienced by society, and therefore the education system, has led to a profound transformation in the teaching-learning process. Faced with a student body that is very different from that of a few years ago, it is necessary for teachers to explore their interests and motivations in order to plan their teaching. For this reason, the inclusion of technology and its application in teaching methods is seen as a solution that motivates students, increases interest in the subject and the content it covers and, as this research has shown, promotes better knowledge acquisition. 
Author Contributions: Conceptualization, G.G.-G.; methodology, F.-D.F.-M.; validation, J.-M.R.-R.; formal analysis, M.R.N.-P.; investigation, F.-D.F.-M. and G.G.-G.; writing-original draft preparation, G.G.-G. and M.R.N.-P.; writing-review and editing, J.-M.R.-R. and G.G.-G.; visualization, F.-D.F.-M.; supervision, F.-D.F.-M. All authors have read and agreed to the published version of the manuscript.

Funding: Ministry of Education, Culture and Sport of the Government of Spain (Project reference: FPU17/05952).

Acknowledgments: To the researchers of the research group AREA (HUM-672). Research group by belonging to the Ministry of Education and Science of the Junta de Andalucía and based in the Department of Didactics and School Organization of the Faculty of Education Sciences of the University of Granada.

Conflicts of Interest: The authors declare no conflict of interest.

\section{References}

1. Agulló-Benito, I. Uso de las TIC para la creación de entornos colaborativos e inclusivos. In Tecnología, Innovación e Investigación en los Procesos de Enseñanza-Aprendizaje; Roig-Vila, R., Ed.; Octaedro: Barcelona, Spain, 2016; pp. 32-39.

2. Konopka, C.L.; Adaime, M.B.; Mosele, P.H. Active teaching and learning methodologies: Some considerations. Creat. Educ. 2015, 6, 1536-1545. [CrossRef]

3. Aguilera-Ruiz, C.; Manzano-León, A.; Martínez-Moreno, I.; Lozano-Segura, M.C.; Yanicelli, C.C. El modelo flipped classroom. Int. J. Dev. Educ. Psychol. 2017, 4, 261-266. [CrossRef]

4. Abellán-Toledo, Y.; Herrada-Valverde, R.I. Innovación educativa y metodologías activas en educación secundaria: La perspectiva de los docentes de lengua castellana y literatura. Fuentes 2016, 18, 65-76. [CrossRef]

5. Hinojo, F.J.; Cáceres, M.P.; Sanz, M.; Gómez, G. Los entornos virtuales de aprendizaje como medio para favorecer la inclusión educativa en la universidad. In Innovación y Tecnología en Contextos Educativos; Sánchez-Rivas, E., Ruiz-Palmero, J., Sánchez-Vega, E., Eds.; Universidad de Málaga: Málaga, Spain, 2019; pp. 871-877.

6. Colomo-Magaña, E.; Soto-Varela, R.; Ruiz-Palmero, J.; Gómez-García, M. University students' perception of the usefulness of the flipped classroom methodology. Educ. Sci. 2020, 10, 275. [CrossRef]

7. Marín-Marín, J.A.; Ramos-Navas-Parejo, M.; Fernández-Campoy, J.M. Metodologías Activas para la Enseñanza Universitaria: Proyecto Enseña+. In Avances en Recursos TIC e Innovación Educativa; Hinojo-Lucena, F.J., Aznar-Díaz, I., Cáceres-Reche, P.M., Eds.; Editorial Dykinson: Madrid, Spain, 2019; pp. 101-116.

8. Mattis, K.V. Instrucción en el aula invertida versus la instrucción tradicional en un libro de texto: Evaluación de la precisión y el esfuerzo mental en diferentes niveles de complejidad matemática. Technol. Conoc. Aprendiz. 2015, 20, 231-248.

9. Young, H.; Jeong, H. Un metaanálisis de los resultados cognitivos, afectivos e interpersonales de las aulas invertidas en la educación superior. Educ. Sci. 2020, 10, 115.

10. Jeong, J.S.; Cañada, F.; González, D. El estudio del aula invertida para profesores de ciencias en formación. Educ. Sci. 2018, 8, 163. [CrossRef]

11. Trujillo, J.M.; Alonso, S.; Romero, J.M.; Gómez-García, G. Experiencias y percepciones del alumnado de Educación Superior sobre Flipped Classroom. In Experiencias en Innovación Docente y Aportes de Investigación Sobre la Praxis Universitaria; Gómez-Galán, J., Cáceres-Reche, P., Delgado-Algarra, E.Y., López-Meneses, E., Eds.; Octaedro: Madrid, Spain, 2019.

12. O'Flaherty, J.; Phillips, C. El uso del aula invertida en la educación superior: Una revisión del alcance. Internet High. Educ. 2015, 25, 85-95.

13. Merla, A.E.; Yañez, C.G. El aula invertida como estrategia para la mejora del rendimiento académico. Rev. Mex. Bachill. Distancia 2016, 8, 68-78. [CrossRef]

14. Basso-Aránguiz, M.; Bravo-Molina, M.; Castro-Riquelme, A.; Moraga-Contreras, C. Propuesta de modelo tecnológico para aula invertida (T-fliC) en educación superior. Rev. Electrón. Educ. 2018, 22, 1-17.

15. Jeong, J.S.; González, D.; Cañada, F. Cómo afecta un curso de aula invertida el dominio afectivo hacia el curso de ciencias? Interactuar. Aprender. Reinar. 2019, 1-13. [CrossRef]

16. Tourón, J.; Santiago, R. Modelo de aprendizaje invertido y desarrollo del talento en la escuela. Rev. Educ. 2015, 368, 33-65. 
17. Carreño, M.M.; Carreño, P.M. El aula invertida versus método tradicional: En la calidad del aprendizaje. Rev. Electrón. Sobre Technol. Educ. Soc. 2019, 6, 1-17.

18. Jiménez Vargas, C.; Guillén Cordero, N. Percepción estudiantil sobre el uso de estrategias didácticas basadas en el modelo pedagógico aula invertida para el logro de aprendizajes significativos en la escuela de secretariado profesional de la Universidad Nacional. Respaldo Rev. Int. Adm. Oficinas Educ. Comer. 2018, 3, 17-37. [CrossRef]

19. Zainuddin, Z.; Habiburrahim, H.; Muluk, S.; Keumala, C.M. How do students become self-directed learners in the EFL flipped-class pedagogy? A study in higher education. Indones. J. Appl. Linguist. 2019, 8. [CrossRef]

20. Hinojo, F.J.; Aznar, I.; Romero, J.M.; Marín, J.A. Influencia del aula invertida en el rendimiento académico. Una revisión sistemática. Campus Virtuales 2019, 8, 9-18.

21. Tse, W.S.; Choi, L.Y.; Tang, W.S. Effects of video-based flipped class instruction on subject reading motivation. Br. J. Educ. Technol. 2019, 50, 385-398. [CrossRef]

22. Miño, R.; Domingo, M.; Sancho, J.M. Transforming the teaching and learning culture in higher education from a DIY perspective. Educación XX1 2018, 22, 139-160. [CrossRef]

23. Hinojo, F.; Mingorance, Á.; Trujillo, J.M.; Aznar, I.; Cáceres, M.P. Incidence of the Flipped Classroom in the Physical Education Students' Academic Performance in University Contexts. Sustainability 2018, 10, 1334. [CrossRef]

24. Báez, C.I.; Clunie, C.E. Una mirada a la Educación Ubicua. Ried Rev. Iberoam. Educ. Distancia 2019, 22, 325-344. [CrossRef]

25. Bognar, B.; Sablić, M.; Škugor, A. Flipped Learning and Online Discussion in Higher Education Teaching. In The Flipped Classroom: Practice and Practices in Higher Education; Reidsema, C., Kavanagh, L., Hadgraft, R., Smith, N., Eds.; Springer: New York, NY, USA, 2019; pp. 371-392. [CrossRef]

26. Sola, T.; Aznar, I.; Romero, J.M.; Rodríguez, A.M. Eficacia del método flipped classroom en la universidad: Meta-análisis de la producción científica de impacto. REICE Rev. Iberoam. Sobre Calid. Efic. Cambio Educ. 2019, 17, 25-38. [CrossRef]

27. Pozo, S.; López, J.; Moreno-Guerrero, A.J.; López, J.A. Impact of Educational Stage in the Application of Flipped Learning: A Contrasting Analysis with Traditional Teaching. Sustainability 2019, 11, 5968. [CrossRef]

28. López-Belmonte, J.; Pozo-Sánchez, S.; Alonso-García, S. Profundización del profesorado español en flipped learning según el nivel de competencia digital. Rev. Interuniv. Form. Profr. 2019, 94, 269-284.

29. Lo, C.K.; Hew, K.F.; Chen, G. Hacia un conjunto de principios de diseño para las aulas cambiadas de matemáticas: Una síntesis de la investigación en educación matemática. Rev. Investig. Educ. 2017, 22, 50-73. [CrossRef]

30. Pozo, S.; López, J.; Moreno-Guerrero, A.J.; Hinojo-Lucena, F.J. Flipped learning y competencia digital: Una conexión docente necesaria para su desarrollo en la educación actual. Rev. Electrón. Interuniv. Form. Profr. 2020, 23, 127-141. [CrossRef]

31. Freeman, S.; Eddy, S.; McDonough, M.; Smith, M.; Okoroafor, N.; Jordt, H.; Wenderoth, M.P. El aprendizaje activo aumenta el rendimiento de los estudiantes en ciencias, ingeniería y matemáticas. Proc. Natl. Acad. Sci. USA 2014, 111, 8410-8415. [CrossRef] [PubMed]

32. Muir, T.; Geiger, V. Las posibilidades de utilizar un enfoque de aula invertida en la enseñanza de las matemáticas: Un estudio de caso de una clase de matemáticas de décimo grado. Math. Educ. Res. J. 2016, 28, 149-171. [CrossRef]

33. Hwang, G.J.; Lai, C.L. Facilitar y establecer un puente entre el aprendizaje dentro y fuera de clase: Un enfoque interactivo de aprendizaje invertido basado en libros electrónicos para cursos de matemáticas. Educ. Technol. Soc. 2017, 20, 184-197.

34. Ruppenthal, S.; Manfroi, L.; Viêra, M.M. Experenciando Flipped Classroom na Aprendizagem da Estatística no Ensino Superior. An. Cent. Ciênc. Soc. Appl. 2019, 6, 99-110.

35. Rojas-Celis, C.; Cely-Rojas, V. Propuesta de enseñanza en Cálculo Vectorial: Un acercamiento a la clase invertida. Rev. Cient. 2020, 1, 58-66. [CrossRef]

36. Jordán, C.; Pérez-Peñalver, M.J.; Sanabria, E. Investigación del impacto en un aula de matemáticas al utilizar flip education. Pensam. Mat. 2014, 4, 9-22.

37. Bhagat, K.K.; Chang, C.N.; Chang, C.Y. El impacto del aula invertida en el aprendizaje de conceptos matemáticos en la escuela secundaria. Rev. Technol. Soc. Educ. 2016, 19, 134-142. 
38. Sacristán-San Cristóbal, M.; Martín, R.D.; Navarro-Asencio, E.; Tourón-Figueroa, J. Flipped classroom y didáctica de las matemáticas en la formación online de Maestros de Educación Infantil. Rev. Electrón. Interuniv. Form. Profr. 2017, 20, 1-14. [CrossRef]

39. Fornons-Jou, V.; Palau-Martín, R.F. Flipped classroom en la asignatura de matemáticas de $3^{\circ}$ de educación secundaria obligatoria. Edutec. Rev. Electrón. De Technol. Educ. 2016, 55, a322. [CrossRef]

40. Pavanelo, E.; Lima, R. Sala de Aula Invertida: A análise de uma experiência na disciplina de Cálculo I. Bolema: Bol. Educ. Mat. 2017, 31,739-759. [CrossRef]

41. Prada, R.; Hernández, C.A.; Gamboa, A.A. Different scenarios for the teaching of mathematics with the support of virtual platforms: Flipped classroom. J. Phys. Conf. Ser. 2019, 1388, 012046. [CrossRef]

42. López, J.; Fuentes, A.; López, J.A.; Pozo, S. Formative Transcendence of Flipped Learning in Mathematics Students of Secondary Education. Mathematics 2019, 7, 1226.

43. Meca, J.S. Cómo realizar una revisión sistemática y un meta-análisis. Aula Abierta 2010, 38, 53-64.

44. Bond, M. Facilitating student engagement through the flipped classroom approach in K-12: A systematic review. Comput. Educ. 2020, 103819. [CrossRef]

45. Pellas, N.; Fotaris, P.; Kazanidis, I.; Wells, D. Augmenting the learning experience in primary and secondary school education: A systematic review of recent trends in augmented reality game-based learning. Virtual Real. 2019, 23, 329-346. [CrossRef]

46. Moher, D.; Liberati, A.; Tetzla, J.; Altman, D.G. PRISMA Group Preferred Reporting Items for Systematic Reviews and Meta-Analyses: The PRISMA Statement. PLoS Med. 2009, 6, e1000097. [CrossRef] [PubMed]

47. Gómez-García, G.; Rodríguez, C.; Marín, J.A. La trascendencia de la Realidad Aumentada en la motivación estudiantil. Una revisión sistemática y meta-análisis. Alteridad 2020, 15, 36-46. [CrossRef]

48. Gómez-García, G.; Hinojo-Lucena, F.J.; Cáceres-Reche, M.P.; Ramos Navas-Parejo, M. The Contribution of the Flipped Classroom Method to the Development of Information Literacy: A Systematic Review. Sustainability 2020, 12, 7273. [CrossRef]

49. Urrutia, G.; Bonfill, X. Declaración PRISMA: Una propuesta para mejorar la publicación de revisiones sistemáticas y metaanálisis. Med. Clín. 2010, 135, 507-511. [CrossRef] [PubMed]

50. Funeme, C.C. El aula invertida y la construcción de conocimiento en matemáticas. El caso de las aplicaciones de la derivada. Tecné Epistem. Didaxis TED 2019, 45, 159-174. [CrossRef]

51. Turra, H.; Carrasco, V.; González, C.; Sandoval, V.; Yáñez, S. Flipped classroom experiences and their impact on engineering students' attitudes towards university-level mathematics. High. Educ. Pedagog. 2019, 4, 136-155. [CrossRef]

52. Umam, K.; Nusantara, T.; Parta, I.N.; Hidayanto, E.; Mulyono, H. An Application of Flipped Classroom in Mathematics Teacher Education Programme. Int. J. Interact. Mob. Technol. (IJIM) 2019, 13, 68-80. [CrossRef]

53. Ahn, K. A Teaching Model for Undergraduate Students. Int. J. High. Educ. 2019, 8, 29-35. [CrossRef]

54. Styers, M.L.; Van Zandt, P.A.; Hayden, K.L. Active learning in flipped life science courses promotes development of critical thinking skills. CBE—Life Sci. Educ. 2018, 17, 39. [CrossRef]

55. Romero-García, C.; Buzón-García, O.; Touron, J. The flipped learning model in online education for secondary teachers. J. Technol. Sci. Educ. 2018, 9, 109-121. [CrossRef]

56. Johnston, B.M. Implementing a flipped classroom approach in a university numerical methods mathematics course. Int. J. Math. Educ. Sci. Technol. 2017, 48, 485-498. [CrossRef]

57. Talbert, R. Inverting the transition-to-proof classroom. Primus 2015, 25, 614-626. [CrossRef]

58. Gouia, R.; Gunn, C. Making mathematics meaningful for freshmen students: Investigating students' preferences of pre-class videos. Res. Pract. Technol. Enhanc. Learn. 2016, 11, 2. [CrossRef] [PubMed]

59. Maciejewski, W. Flipping the calculus classroom: An evaluative study. Teach. Math. Its Appl. Int. J. IMA 2016, 35, 187-201. [CrossRef]

Publisher's Note: MDPI stays neutral with regard to jurisdictional claims in published maps and institutional affiliations. 